Buana Sains Vol 18 No 1: 67 - 72, 2018

\title{
PENGARUH METODE EKSTRAKSI MINYAK PUPA ULAT JERMAN TERHADAP KOMPOSISI KIMIA
}

\author{
Erik Priyo Santoso dan Farida Kusuma Astuti \\ Program Studi Peternakan, Fakultas Pertanian, Universitas Tribhuwana Tunggadewi
}

\begin{abstract}
The aim of this research is to know the extraction method of caterpillar pupa without detrimental to chemical composition to know the amount of pupa production of German caterpillar with two extraction methods per 100 grams of pupa To know the content of dry matter, organic matter, crude protein, crude fat, crude fiber and amino acid lysin, methionine, and vitamin E pupa oil of German caterpillar. The study was conducted from February to April 2017, at the Lab. Central University Tribhuwana Tunggadewi. Oil extraction analysis was conducted in the chemistry laboratory of Tribhuwana Tunggadewi University and chemistry laboratory of Poltek Malang. German caterpillar research material, German caterpillar pupa, pupa caterpillar germany extracted by maceration and sokletasi. German caterpillar pupa is obtained from German caterpillar breeders in Amadanom, Dampit, Malang Regency. This research uses two different extraction methods, namely cold extraction method (maseration method) and using heat method (soxhlet method). The conclusions of both research methods are known that the quantity of German caterpillar yield using soxhlet extraction method is more than the maceration extraction method. However, for the quality of the two methods it is still necessary to do further analysis to know the exact comparison of the two methods.
\end{abstract}

Keywords: German caterpillar; extraction; chemical content; soxhlet method, maseration method.

\section{Pendahuluan}

Ulat jerman yang dikenal dengan nama king mealworm (Zophobas morio) merupakan bahan pakan popular yang banyak digunakan para penghobi untuk diberikan kepada reptil, burung kicauan, dan unggas lainnya. Penggemar burung dan reptil di mancanegara sering menyebutnya superworm. Ukuran tubuhnya lebih besar daripada ulat hongkong. Nilai gizinya pun lebih tinggi. Bukan hanya itu, ulat jerman juga dianggap lebih aman ketimbang ulat hongkong yang banyak digunakan penggemar burung di Indonesia.
Belakangan ini budidaya ulat jerman mulai marak di Indonesia, meski jumlahnya masih sedikit apabila dibandingkan dengan jumlah pembudidaya ulat hongkong. Awalnya, bibit ulat jerman didatangkan dari Amerika Tengah dan Amerika Selatan. Sekarang bibit ulat jerman tidak perlu impor lagi, karena sudah banyak yang mengembangbiakkannya di Indonesia untuk pakan burung dan reptil. Selain itu, kandungan protein dan zat gizi lainnya pada ulat jerman juga lebih tinggi daripada ulat hongkong. Bahkan, ulat jerman juga memiliki sistem kekebalan tubuh yang lebih tinggi, sehingga ketika termakan burung bisa membantunya 
E. P. Santoso dan F.K. Astuti/ Buana Sains Vol 18 No 1 : 67-72

dalam menangkal berbagai agen penyakit seperti virus, bakteri, jamur, maupun parasit. Berikut ini beberapa kandungan gizi pada ulat jerman : Protein : 19,06 \%, Lemak : 14,19\%, Kalsium : 173 ppm, Serat kasar: 2,60\% (Munandi, 2015).

Pemanfaatan ulat jerman di kalangan masyarakat sampai saat ini hanya digunakan sebagai pakan burung, belum ada pemanfaatan lebih lainnya. Hal ini dikarenakan belum terungkap tentang kandungan nilai nutrisi pupa ulat jerman atau minyak hasil ekstraksi pupa ulat jerman. Lain halnya ulat sutera (Bombyx mori), pemanfaatan ulat sutera sudah sampai dengan pemanfaatan pupa, dan molt, yang digunakan sebagai bahan kosmetik dan pangan fungsional.

Kemudahan budidaya ulat jerman dibanding dengan ulat sutera merupakan salah satu daya tariknya. Ulat jerman tahan di suhu tropis dan pakan konsentrat dengan kualitas rendah semisal onggok. Berbeda dengan ulat sutra yang menginginkan suhu rendah $25^{\circ} \mathrm{C}$ dengan kelembaban $80-90 \%$ dan pakan daun murbei.

\section{Metode Penelitian}

Penelitian dilaksanakan mulai dari bulan Februari sampai dengan bulan Maret 2017, di Lab. Sentral Universitas Tribhuwana Tunggadewi. Analisis ekstraksi minyak dilakukan di laboratorium kimia Universitas Tribhuwana Tunggadewi dan Politeknik negeri malang. Materi penelitian berupa ulat jerman, pupa ulat jerman, minyak pupa ulat jerman hasil ekstraksi maserasi dan sokletasi. Pupa ulat jerman di peroleh dari peternak ulat jerman di Amadanom, Dampit Kabupaten Malang. Penelitian ini menggunakan dua metode ekstraksi yang berbeda yaitu metode ekstraksi dingin (metode maserasi) dan mengunakan metode panas (sokletasi)

\section{Ekstraksi maserasi}

Pengambilan minyak Pupa ulat jerman dengan metode maserasi dilakukan dengan prosedur pertama yaitu pupa ulat jerman di potong kecil-kecil dan direndam kedalam pelarut dengan perbandingan 1: 3, 1 untuk berat pupa ulat jerman dan 3 untuk volume pelarut yang digunakan. Kemudian dilaku- kan proses maserasi, dengan pengadukan selama 1 menit secara manual pada suhu ruang dan tanpa terkena cahaya (ditempat tertutup dan gelap) didiamkan selama 12 jam. Kemudian ekstrak minyak pupa dipisahkan dengan cara penyaringan dan pemerasan sehingga diperoleh ampas dan filtrat. Filtrat yang mengandung minyak pupa ulat jerman dievaporasi dengan rotary vacuum evaporator pada suhu $50-60^{\circ} \mathrm{C}$, untuk memisahkan antara pelarut dengan minyak poupa ulat jerman. Setelah didapatkan minyak pupa ulat jerman, dihitung rendemen dan dilakukan uji asam amino

\section{Data pengamatan}

Sampel $=100,08$ gram, Pelarut $=\mathrm{N}$ Heksana (pro analis), Jumlah pelarut $=1$ : 3 sampel ; pelarut, Kebutuhan pelarut $=$ 300 gram $=454,5 \mathrm{ml}$, Hasil maserasi $=6$ $\mathrm{ml}$, Kondisi operasi $=$,Dilakukan selama 24 jam dengan suhu ruang $\pm 27^{\circ} \mathrm{C}$

\section{Ekestraksi soleletasi}

Pengambilan minyak Pupa ulat jerman dengan metode sokletasi dilakukan dengan prosedur pertama yaitu pupa ulat jerman direbus dan di keringkan lalu di tumbuk samapi halus, di timbang dan dilakukan proses ekstraksi secara sokletasi dengan pelarut n-heksan selama kurang lebih 5 jam. Setelah didapatkan minyak pupa ulat jerman dilakukan uji kandungan asam amino dan analisa GCMS 


\section{Pembahasan}

\section{Budidaya ulat jerman}

Ulat jerman yang di gunakan dalam penelitian ini berasal dari salah-satu peternak di desa amandamon, kecamatan dampit kabupaten malang. Ulat jerman yang dibeli dari peternak berumur 50 hari dengan bobot rata-rata $0,56 \mathrm{gr}$ dengan panjang rata-rata $5,2 \mathrm{~cm}$. Untuk dijadikan serangga di butuhkan ulat dewasa dengan umuri 110 hari dengan bobot rataan 1,1gr dengan panjang $7 \mathrm{~cm}$. sehingga di butuhkan waktu pemeliharaan kurang lebih selama dua bulan dengan penambahan bobot badan 0,54 untuk memenuhi target tersebut ulat jerman yang di budidayakan diberikan media pakan polar dengan tambahan buahbuahan serta sayuran: papaya muda, manisa, sawi sebagai sumber air minum ulat.

\section{Pupa ulat jerman}

Ulat jerman yang telah berumur 110 hari di pisah dalam wadah tersendiri untuk dijadikan serangga, perubahan dari ulat menjadi serangga membutuhkan waktu 1 samapai 2 minggu hal ini sangat tergantung dari kondisi ulat tersebut seperti pada gambar 1 .

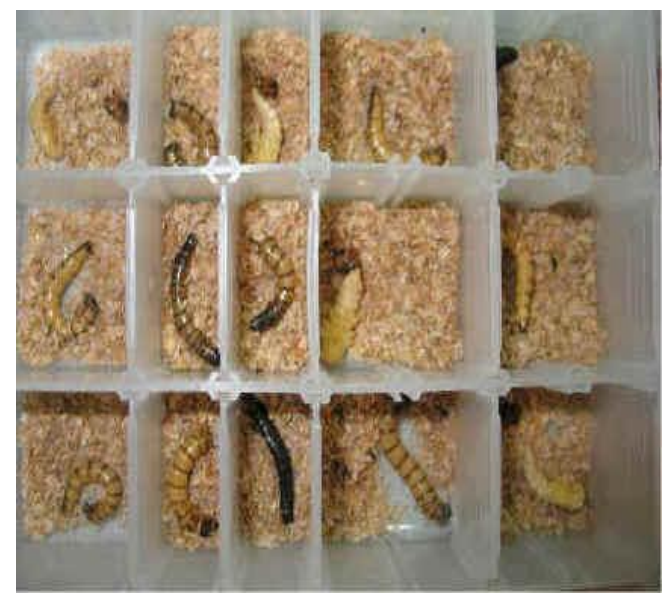

Gambar 1. Proses perubahan ulat menjadi pupa

\section{Exstraksi}

Penelitian ini bertujuan untuk mengetahui pengaruh metode ektraksi minyak ulat jerman terhadap komposi kimia dengan membandingkan dua metode ekstraksi yang berbeda. Metode pertama yaitu digunakan ekstraksi sokletasi dan kedua menggunakan metode maserasi. Dalam praktiknya kedua metode ini menggunakan jenis pelarut yang sama yaitu N-heksana (pro Analis). Jenis pelarut tersebut dipilih dengan mempertimbangkan kelarutan senyawa yang akan di ekstraksi dengan jenis pelatutnya. Dimana pada umumnya minyak nabati akan larut dengan baik menggunakan pelarut organic seperti benzene dan heksana. Sedangkan grade pro analis dipilih dengan memperhatikan proses selanjutnya yaitu analisa komponen menggunakan Liquid Cromatography Mass Spectrometer ( LCMS). Adapaun proses ektrasi yang dilakukan sebagai berikut :

\section{Data Pengamatan}

1. Ekstraksi sokletasi, Sampel kering = 100,6 gram, Pelarut $=400 \mathrm{ml} \mathrm{N}$ heksana ( pro analis ), Hasil ekstrasi $=$ $56 \mathrm{ml}$, Kondisi operasi = ,Ektraksi silakukan dengan mengulang sirkulasi sebanyak $7 \mathrm{x}$ pada suhu $\pm 70^{\circ} \mathrm{C}$

2. Ekstrasi maserasi, Sampel $=100,8$ gram, Pelarut $=$ N-Heksana (pro analis ), Jumlah pelarut $=1: 3$ sampel ; pelarut, Kebutuhan pelarut $=300$ gram $=454,54 \mathrm{ml}$, Hasil maserasi $=6$ $\mathrm{ml}$, Kondisi operasi $=$, Dilakukan selama 24 jam dengan suhu ruang \pm $27^{\circ} \mathrm{C}$ 


\section{Perbandingan hasil ekstraksi dengan metode sokletasi dan maserasi}

Penelitian ini bertujuan untuk mengetahui pengaruh metode ektraksi minyak ulat jerman terhadap kompisi kimia dengan membandingkan dua metode ekstraksi yang berbeda. Metode pertama yaitu digunakan ekstraksi sokletasi dan kedua menggunakan metode maserasi. Dalam praktiknya kedua metode ini menggunakan jenis pelarut yang sama yaitu N-heksana (pro Analis). Jenis pelarut tersebut dipilih dengan mempertimbangkan kelarutan senyawa yang akan di ekstraksi dengan jenis pelatutnya. Dimana pada umumnya minyak nabati akan larut dengan baik menggunakan pelarut organic seperti benzene dan heksana. Sedangkan grade pro analis dipilih dengan memperhatikan proses selanjutnya yaitu analisa komponen menggunakan Liquid Cromatography Mass Spectrometer ( LCMS). Adapaun proses ektrasi yang dilakukan sebagai berikut :

\section{Ektraksi dengan metode sokletasi}

Pada proses ektraksi sokletasi sampel yang digunakan adalah sampel kering berupa bubuk ulat jerman sebanyak 100,6 gram. Sampel tersebut di bungkus dengan kertas saring untuk di kontakkan dengan pelarut. Pada proses ektraksi ini sampel sengaja di tumbuk menjadi ukuran yang lebih kecil dengan tujuan memperluas bidang kontak antara pelarut dan sampel yang akan di ekstraksi. Proses ini dilakukan secara berulang hingga pelarut jenuh dan dilakukan pada suhu $\pm 70^{\circ} \mathrm{C}$. Hal ini berkaitan dengan titik didih pelarut yang digunakan dan juga agar komponen yang dianalisa tidak rusak selama proses. Proses ekstraksi soxhlet ini sendiri dilakukan berulang hingga $7 x$ proses sirkulasi. Dimana pada prinsipnya proses ekstraksi soxhlet adalah metode penyaringan berulang sehingga hasil yang di dapat sempurna. Hal ini dapat di tunjukkan pada lampiran 1. Dari gambar tersebut terlihat pada siklus pertama larutan cenderung pekat karena komponen yang diekstraksi masih banyak. Kemudian pada gambar 12. terlihat bahwa pelarut mulai pudar, hal ini menandakan bahwa konsentrasi zat yang akan di ekstraksi semakin sedikit karena telah mengalami pengulangan sebanyak 4x. kemudian pada 13. Terlihat bahwa saat proses sirkulasi ke 7 pelarut kembali berwarna bening yang menandakan bahwa sudah tidak ada lagi komponen yang dapat di ekstraksi. Sedangkan 15. menunjukan bahwa pelarut yang digunakan dapat di pisahkan kembali dari hasil ektraks dikarenakan setelah proses penyaringan selesai . sehingga maka pelarut yang digunakan diuapkan kembali dan hanya sisa zat yang tersaring. Dari hasil pemisahan tersebut di peroleh minyak ulat jerman sebanyak $56 \mathrm{ml}$ dari 100,06 gram sampel. Untuk mengetahui komponen dalam sampel yang telah di ekstrak maka perlu dilakukan analisa mendalam yaitu dengan Liquid Cromatography Mass Spectrometer ( LCMS). Hasil ekstraksi dapat terlihat seperti pada gambar 2 .

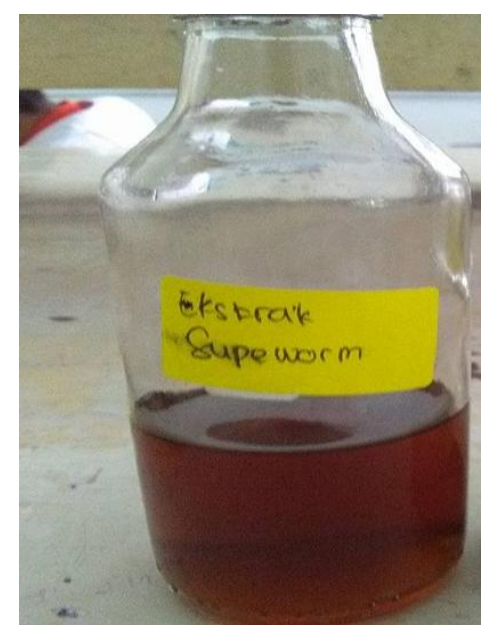

Gambar 2. Hasil ektraksi metode sokletasi 


\section{Ekstraksi dengan metode maserasi}

Pada proses maserasi sampel yang digunakan merupakan pupa ulat jerman yang dipotong kecil - kecil. Pemotongan tersebut bertujuan untuk memperluas bidang kontak antara sampel dan pelarut. Sedangkan pelarut yang digunakan adalah menggunakan pelarut N-Heksana ( pro analis ) dengan perbandingan 3 : 1 dari jumlah sampel. Penelitian ini menggunakan sampel sebanyak 100,08 gram sedangkan kebutuhan pelarut yang di butuhkan adalah sebanyak 300 gram atau setara dengan 454,54 $\mathrm{ml}$ dengan memperhitungkan densitas daripada $\mathrm{n}$ heksana p.a. proses maserasi ini dilakukan selama 24 jam dengan suhu ruang $\pm 27^{\circ} \mathrm{C}$. hal ini berkaitan dengan prinsip metode maserasi. Dimana metode maserasi ini merupakan cara ekstrasi sederhana yang dilakukan dengan cara merendam bahan dalam pelarut selama beberapa jam atau hari pada suhu ruang dan terlindung dari cahaya matahari. Setelah proses maserasi berlansung selama 24 jam, barulah dipisahkan antara minyak dan pelarut. Yang kemudian ekstrak minyak pupa dipisahkan dengan penyaringan dan pemerasan sehingga diperoleh filtrat dan ampas. Filtat yang mengandung minyak ulat jerman kemudian di evaporasi untuk memisahkan antara pelarut dan minyak pupa ulat jerman. sedangkan untuk analisa komponen perlu dilakukan analisa lebih lanjut menggunakan Liquid Cromatography Mass Spectrometer ( LCMS).Hasil ekstraksi dengan metode maserasi ditunjukan pada gambar 3

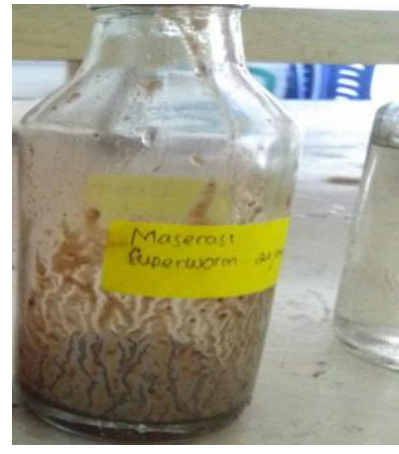

Gambar 3. Hasil ekstraksi dengan metode maserasi.

\section{Kesimpulan}

Dari kedua metode penelitian yang dilakukan diketahui bahwa secara kuantitas hasil minyak ulat jerman menggunakan metode ekstraksi sokletasi lebih banyak dari pada proses maserasi Namun untuk kualitas dari kedua metode tersebut masih perlu dilakukan analisa lanjut agar diketahui secara pasti perbandingan dari kedua metode tersebut.

\section{Daftar Pustaka}

Anonimus, 2015. Budidaya Superworm, Prospek usaha yang sangat menggiurkan

Dimas Sudiyanto, 2013, Inovasi Baru Pengembangan Kerupuk Pupa Ulat Sutera (Bombyx mori) dengan Menggunakan Teknik Deep Frying dan Microwave, dimassudiyanto.blogspot.com/20 13/01/pupa-ulat-sutra.html， 20 September 2014.

Haffandi, L. 2012. Analisis Sampah Organik Dan Anorganik Di Tps Kota Malang. http://lindahaffani.blogspot.com/2013/03/a nalisis-sampah-organik-dananorganik.html. Diakses tanggal 4 Maret 2013. 
Harborne, J. B. 1996. Metode Fitokimia. Terbitan ke-II a.b. Kosasih Padmawinata Penerbit ITB Bandung

Munandi, A. 2015. Ulat jerman lebih aman daripada ulat hongkong www.

http://omkicau.com/2013/09/2

2/ulat-jerman-lebih-amandaripada-ulat-hongkong/.

Diakses tanggal 20 April 2015

Shawar Khan, 2011, Memanfaatkan Protein dari Pupa Ulat Sutra Bombyx mori sebagai Bahan Fortifikasi pada SusuBubuk, PKM, IPB, www. Ciputra entrepreneurship.com,20

September 2014

Userlele,2011.Ulat jerman /superworm. www.https://hanndyanifarm.wor dpress.com/2011/09/17/ulatjerman-superworm/. Diakses tanggal 21 April 2015. 